\title{
Transglutaminase 2 mRNA Expression in Salivary Gland Tumor Cell Line
}

\author{
Yoon Kwon Chun, Chong Heon Lee \\ Department of Oral Pathology, The Oral Aging Research Center, College of Dentistry, Dankook University, Cheonan, Korea
}

Purpose: Transglutaminase 2 (TGase 2) is expressed by tumor necrosis factor- $\alpha$ in various carcinoma. The role of TGase 2 expression in salivary gland tumors is not clear yet. Established slaivary gland tumor (SGT)cell line has been used to study the pathogenesis of salivary gland adenocarcinoma on a cellular level in vitro. The pupose of this study were to examine mRNA expression of TGase 2 in SGT cell line compared to other tumor cell lines, and to apply these results to the pathogenesis of salivary gland tumor.

Materials and Methods: After SGT, SCC-15, HN 4, and HeLa tumor cell lines were cultured under preconfluency, and 3 days after postconfluency, the cells were harvested for total RNA extraction and cDNA preparation.

Result: Reverse transcription polymerase chain reaction for semiquantitative mRNA analysis was done. TGase 2 mRNA expression was not induced by confluency in all the cell lines. TGase 2 mRNA expression was variable but markedly enhanced in SGT cell line.

Conclusion: mRNA expression of TGase 2 should play an important role in the pathogenesis of SGT cell line originated from ductal cell.

Key Words: Salivary gland tumor; TGase 2 expression

\section{Introduction}

Transglutaminase 2 (TGase 2) in cytosolic and nuclear area is assoacitated with apoptosis, GTP binding protein, and cell marix interaction ${ }^{1,2)}$. The role of TGase 2 is controversial about involvement in the pathogenesis of cancer, and the function of TGase 2 in salivary gland tumors is not clear yet. Slaivary gland tumor (SGT) cell line from human submandibular gland adenocarcinoma has been studied to get considerable characteristic molecular studies of cancer on a cellular level in $v$ itro $^{3)}$. It was reported that the highest TGase 2 enzyme activity of SGT cell line compared to other

Corresponding Author: Chong Heon Lee

Department of Oral Pathology, College of Dentistry, Dankook University, 119 Dandae-ro, Dongnam-gu, Cheonan 330-714, Korea

TEL : +82-41-550-1946, FAX : +82-41-559-7898, E-mail : chleeop@naver.com

Received for publication June 7, 2013; Accepted for publication June 14, 2013

Copyright $\odot 2013$ by Korean Academy of Dental Science

cc This is an open access article distributed under the terms of the Creative Commons Attribution Non-Commercial License (http://creativecommons.org/licenses/ by-nc/3.0) which permits unrestricted non-commercial use, distribution, and reproduction in any medium, provided the original work is properly cited. 
tumor cell lines should be an important role in the pathogenesis of salivary gland adenocarcinoma. To understand roles of TGase 2 in salivary gland tumor, it is necessary to study the effector of TGase 2 for revealing regulatory mechanisms in molecular level. The plausible candidate among methods is reverse transcription- polymerase chain reaction (RT-PCR) technique for TGase 2 mRNA expression because this methods can detect very lower mRNA expression in most tissues and cell lines. We used RT-PCR method with TGase 2 primer as experiment and human-actin primer as control.

The puposes of this study were to examine mRNA expression of TGase 2 in SGT cell line, and to apply these results to the pathogenesis of salivary gland tumor.

\section{Materials and Methods}

\section{Culture Conditions of Tumor Cell Line}

SGT, SCC-15, HN4, and HeLa cell line were cultured under Dulbecco's modified Eagle's medium (DMEM, Hyclone, Rockville, MD, USA) $10 \%$ FBS containing penicillin at $37^{\circ} \mathrm{C}$ in a $5 \% \mathrm{CO}_{2}$ incubator. In 70 80\% confluency, the cells were treated with $0.05 \%$ trypsin and EDTA (Clonetics, Rockville, MD, USA) in calcium and magnesium free PBS (pH 7.3). Subculture was made on 4 or 5 day intervals.

\section{Morphologic Observation}

After SGT, SCC-15, HN 4, and HeLa tumor cell line were cultured under preconfluency, and 3 days after postconfluency, these cells were examined with Inverted microscope.

\section{Total RNA Extraction from SGT, SCC-15, HN} 4, and HeLa Cell Lines for Reverse TranscriptionPolymerase Chain Reaction

Tumor cell lines grew 70 80\% in the $100 \mathrm{~mm}$ culture dish (GibcoBRL, Rockville, MD, USA), the culture media were removed and washed with $\mathrm{pH}$

\subsection{PBS (GibcoBRL).}

The Guanidinium thiocyanate method was used to isolate total RNA. Guanidinium thiocyanate solution (4 M guanidinium thiocyanate, 1\%mercatpethanol, $0.1 \mathrm{M}$ Tris- $\mathrm{Cl} \mathrm{pH} 7.5)$. The final dried RNA was solubilized in diethyl pyrocarbonate-treated (DEPC) water. The A 260/280 ratio of purified RNA was measured over 1.8 by spectrophotometer. The quality of RNA has been confirmed by electrophoresis on $1 \%$ agarose gel containing ethium bromide (120 V, 2 3 hours).

\section{Reverse Transcription-Polymerase Chain Reaction for cDNA}

The reverse transcription reaction of the RNA was performed 2 hours at $42^{\circ} \mathrm{C}$ using avian myelo-blastosis virus (AMV), and $1.0 \mu \mathrm{l}$ of this was used for templates of the all PCR. The PCR condition was one cycle 2 minutes at $95^{\circ} \mathrm{C}, 25$ cycle each 30 second at $95^{\circ} \mathrm{C}, 55^{\circ} \mathrm{C}, 72^{\circ} \mathrm{C}$ and one cycle 10 minutes at $72^{\circ} \mathrm{C}$ with ${ }^{32} \mathrm{P}$-dCTP labeling using PCR machine. The TGase 2 (antisense: CTCGTGGAGCCAGTTATCAACAGCTAC and sense: TCTCGAAGTTCACCACCAGCTTGTG) primers was used and normal human $\beta$-actin (822bp) as a control group was amplified as the aboving method. The PCR product was separated using $2 \%$ agarose gel and dried in the gel dryer, which was developed and was then measured with the semi-quantitative method using a densitometer in triplicate and was compared to each other after each mRNA level divided by normal human $\beta$-actin mRNA levels.

\section{Result}

\section{Morphologic Features}

SGT tumor cell line showed spindle or ovoid shaped cells with long process forming duct-like formation. SCC-15 tumor cell line showed spindle or ovoid cells with large nucleus. HN 4 tumor cell line showed polyhedral shaped cells with distinct 
membrane and large nucleus. HeLa tumor cell line showed spindle shaped cells with long process associated with each other.

2. mRNA Measurement of TGase 2 in SGT, SCC15, HN 4, and HeLa Cell Lines

SGT showed the highest mRNA expression of TGase 2 (Fig. 1). SGT showed 6 8 folds elevation of TGase 2 than other cell lines, while HN 4 showed less mRNA expression of TGase 2 than that of SCC15 and HeLa (Fig. 2). Under postconfluency all cell lines showed less mRNA expression of TGase 2 than that under preconfluency (Fig. 2).

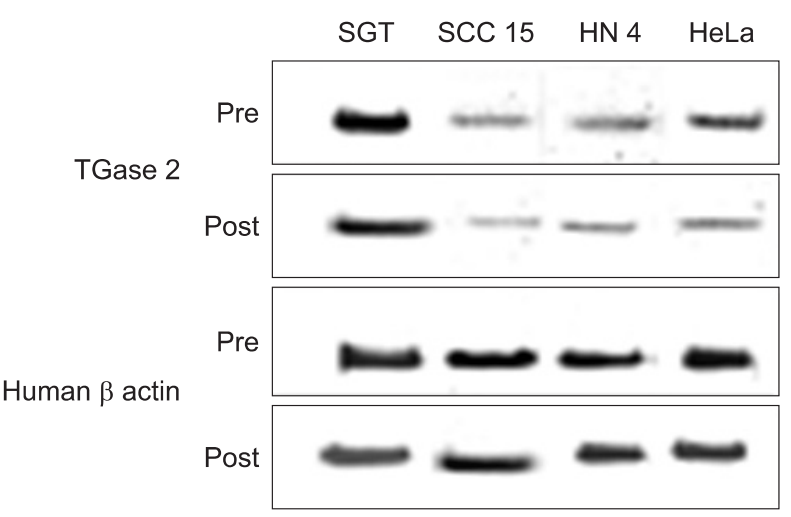

Fig. 1. TGase 2 mRNA expression in SGT, SCC-15, HN4, and HeLa cell line. SGT showed the highest expression than any other cell lines by reverse transcription-polymerase chain reaction.

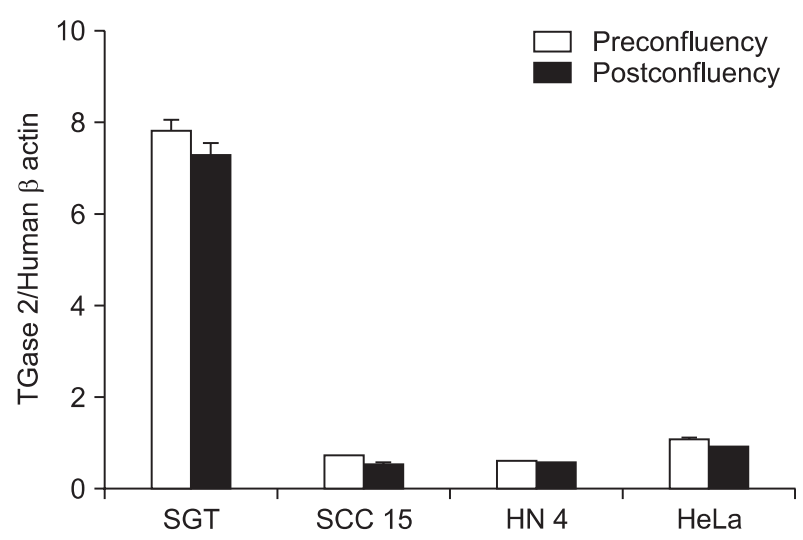

Fig. 2. TGase 2 mRNA expression of SGT showed $6 \sim 8$ folds elevation than other cell lines by reverse transcription-polymerase chain reaction.

\section{Discussion}

TGase 2 is a $77 \mathrm{kD}$ enzyme expressed in several tissues, but the role of TGase 2 in cancer biology has not been established and controversial. Intracellular TGase have been demonstrated by immunohistochemistry in many tissues ${ }^{4)}$. TGase 2 is proposed to be involved in the apoptotic body formation during the cell death process ${ }^{5}$. A direct relationship between TGase activity and detergent insoluble apoptotic body formation has been reported in human cancer cell lines ${ }^{6}$. Although there was no interesting change in all the tumor cell lines after post-confluence, all the cell lines showed decreased TGase 2 expression under postconfluency. This suggested that tumor cell lines would progress to the cellular apoptosis in molecular level.

Physiological role of TGase 2 expression is not clear yet in slaivary gland carcinoma. Although all the tumor cell lines expressed variable amounts of TGase 2, this up-regulation of TGase 2 expression in SGT cell line suggested that TGase 2 should regulate tumor growth and metastasis. It was presented that TGase 2 expression contributed to the deranged adhesive properties of the bladder carcinoma cells and a influence the course of invasion $^{7}$. It was thought that TGase 2 expression is a prerequisite for invasion. In vitro experimental findings have suggested that TGase 2 activity can promote the stable attachment of tumor cells to fibroectin ${ }^{8)}$. The transfection and overexpression of TGase 2 in mammalian cells deficient in TGase 2 provides direct evidence that TGase 2 expression can modify cellular adhesion".

TGase 2 showed a range of biochemical activities that potentially may influence the development of cancer ${ }^{10)}$. An inverse relationship between TGase 2 activity and metastatic potential as been reported $^{11-15)}$. It was thought that TGase 2 expression influences the tendency of the primary tumour to metastasize. TGase negative tumor cells might 
escape to the blood stream, and these cells might exhibit a higher tendency to metastasize ${ }^{8)}$. Metastatic potential reported in B16 melanoma cells ${ }^{13)}$, and relatively low expressed TGase 2 activity mRNA amount in HeLa cell line, suggesting that TGase 2 might regulate metastatic potentiality. From this theory SGT cell line with the highest TGase 2 expresion might have tendency of invasive ability more than metastasized ability. But it is difficult to predict the net effect of the TGase 2 expression on the basis of its biochemical properties ${ }^{16)}$.

It is necessary to study another candidate factor associated with TGase 2 expression. Cytokines would be the plausible candidates of effectors. Many reports demonstrated the differential expression of cytokines from the different source of transformed SCCs and cancer tissues ${ }^{17-21)}$. The investigation of TGase 2 expression in the various lung carcinoma cell lines ${ }^{17)}$ and in the SCCs ${ }^{22)}$ showed that the level of these enzymes derived from cell line to cell line. This might be due to the differential expression of cytokines. Much less is known about the relationship between TGase 2 and cytokines in salivary gland tumors. Tumor necrosis factor- $\alpha$ (TNF- $\alpha$ ) enhanced the growth of the Human acinic cell carcinoma (HACC) line significantly, but there was no evidence of autocrine growth using these growth factors ${ }^{23)}$. The HACC cell line has features similar to both acinar and intercalated ductal cells of the salivary gland. Epidermal growth factor and TNF- $\alpha$ are potential growth factors for the HACC cell line ${ }^{23)}$.

These heterogenity of functions suggested that TGase 2 and cytokines expression might play different roles dependent on the tissue or cell type in which they are expressed. Although no distinct function on the molecular level has been described for TGase 2 expression in SGT cell line. Although the relationships between TGase 2 and cytokines mRNA expression was not examined, this study was the first time that mRNA expression of TGase 2 was described and characterized in adenocarcinoma
NOS derived from human salivary gland. Further studies will show that TGase 2 and cytokines can be used as a functional marker for the pathogenesis of salivary gland tumor.

\section{Conclusion}

After examining mRNA expression of TGase 2 in SGT cell line compared to other tumor cell lines, it suggested that higher mRNA expression of TGase 2 might play an important role in the pathogenesis of SGT cell line originated from human salivary gland ductal cell.

\section{References}

1. Upchurch HF, Conway E, Patterson MK Jr, Maxwell MD. Localization of cellular transglutaminase on the extracellular matrix after wounding: characteristics of the matrix bound enzyme. J Cell Physiol. 1991; 149: 375-82.

2. Schittny JC, Paulsson M, Vallan C, Burri PH, Kedei $\mathrm{N}$, Aeschlimann D. Protein cross-linking mediated by tissue transglutaminase correlates with the maturation of extracellular matrices during lung development. Am J Respir Cell Mol Biol. 1997; 17: 334-43.

3. Shrestha P, Sumitomo S, Lee CH, Nagahara K, Kamegai A, Yamanaka T, Takeuchi H, Kusakabe M, Mori M. Tenascin: growth and adhesion modulation--extracellular matrix degrading function: an in vitro study. Eur J Cancer B Oral Oncol. 1996; 32B: 106-13.

4. Thomázy V, Fésüs L. Differential expression of tissue transglutaminase in human cells. An immunohistochemical study. Cell Tissue Res. 1989; 255: 215-24.

5. Fesus L, Thomazy V, Falus A. Induction and activation of tissue transglutaminase during programmed cell death. FEBS Lett. 1987; 224: 104-8.

6. Piacentini M, Fesus L, Farrace MG, Ghibelli L, Piredda L, Melino G. The expression of "tissue" 
transglutaminase in two human cancer cell lines is related with the programmed cell death (apoptosis). Eur J Cell Biol. 1991; 54: 246-54.

7. Hettasch JM, Bandarenko N, Burchette JL, Lai TS, Marks JR, Haroon ZA, Peters K, Dewhirst MW, Iglehart JD, Greenberg CS. Tissue transglutaminase expression in human breast cancer. Lab Invest. 1996; 75: 637-45.

8. Hager H, Jensen PH, Hamilton-Dutoit S, Neilsen MS, Birckbichler P, Gliemann J. Expression of tissue transglutaminase in human bladder carcinoma. J Pathol. 1997; 183: 398-403.

9. Gentile V, Thomazy V, Piacentini M, Fesus L, Davies PJ. Expression of tissue transglutaminase in Balb-C 3T3 fibroblasts: effects on cellular morphology and adhesion. J Cell Biol. 1992; 119: 463-74.

10. Aeschlimann D, Paulsson M. Transglutaminases: protein cross-linking enzymes in tissues and body fluids. Thromb Haemost. 1994; 71: 402-15.

11. Hand D, Elliott BM, Griffin M. Expression of the cytosolic and particulate forms of transglutaminase during chemically induced rat liver carcinogenesis. Biochim Biophys Acta. 1988; 970: 137-45.

12. Knight CR, Rees RC, Griffin M. Apoptosis: a potential role for cytosolic transglutaminase and its importance in tumour progression. Biochim Biophys Acta. 1991; 1096: 312-8.

13. Beninati S, Abbruzzese A, Cardinali M. Differences in the post-translational modification of proteins by polyamines between weakly and highly metastatic B16 melanoma cells. Int J Cancer. 1993; 53: 792-7.

14. Barnes RN, Bungay PJ, Elliott BM, Walton PL, Griffin M. Alterations in the distribution and activity of transglutaminase during tumour growth and metastasis. Carcinogenesis. 1985; 6: 459-63.

15. Zirvi KA, Keogh JP, Slomiany A, Slomiany BL. Transglutaminase activity in human colorectal carcinomas of differing metastatic potential. Cancer Lett. 1991; 60: 85-92.
16. Mian S, el Alaoui S, Lawry J, Gentile V, Davies PJ, Griffin M. The importance of the GTP-binding protein tissue transglutaminase in the regulation of cell cycle progression. FEBS Lett. 1995; 370: 27-31.

17. Levitt ML, Gazdar AF, Oie HK, Schuller H, Thacher SM. Cross-linked envelope-related markers for squamous differentiation in human lung cancer cell lines. Cancer Res. 1990; 50: 120-8.

18. Mann EA, Spiro JD, Chen LL, Kreutzer DL. Cytokine expression by head and neck squamous cell carcinomas. Am J Surg. 1992; 164: 567-73.

19. Woods KV, El-Naggar A, Clayman GL, Grimm EA. Variable expression of cytokines in human head and neck squamous cell carcinoma cell lines and consistent expression in surgical specimens. Cancer Res. 1998; 58: 3132-41.

20. Knerer B, Hulla W, Martinek H, Formanek M, Temmel A, Kornfehl J. IL-1 and TNF-alpha but no IL-2 expression is found in squamous cell carcinomas of the head and neck by RT-PCR. Acta Otolaryngol. 1996; 116: 132-6.

21. Fahey MS, Paterson IC, Stone A, Collier AJ, Heung YL, Davies M, Patel V, Parkinson EK, Prime SS. Dysregulation of autocrine TGF-beta isoform production and ligand responses in human tumourderived and Ha-ras-transfected keratinocytes and fibroblasts. Br J Cancer. 1996; 74: 1074-80.

22. Duvic M, Nelson DC, Annarella M, Cho M, Esgleyes-Ribot T, Remenyik E, Ulmer R, Rapini RP, Sacks PG, Clayman GL, Davies PJA, Thacher S. Keratinocyte transglutaminase expression varies in squamous cell carcinomas. J Invest Dermatol. 1994; 102: 462-9.

23. Fukuda T, Tominaga K, Abe M, Kusakabe T, Yamaki T, Hiraki H, Itoh S, Suzuki T. Characterization of a newly established human acinic cell adenocarcinoma cell line (HACC) originating from the salivary gland: morphological features and role of various growth factors on the growth of the HACC cell line. Pathol Int. 1998; 48: 791-9. 